\title{
Vaginitis: Etiology and Role of Oxidative Stress, Inflammation and Antioxidants Therapy
}

\section{Fazele Heydarian Moghadam ${ }^{1}$, Mojgan Tansaz ${ }^{1}$, Soheila Aminimoghaddam ${ }^{2}$, Homa Hajimehdipoor and Hamed Hosseini ${ }^{4}$}

\begin{abstract}
${ }^{1}$ Department of Traditional Medicine School of Traditional Medicine, Shahid Beheshti University of Medical Sciences, Tehran, Iran

${ }^{2}$ Department of Gynecology and Oncology ,Firoozgar Hospital, Iran University of Medical Sciences, Tehran, Iran ${ }^{3}$ Traditional Medicine and Materia Medica Research Center, Department of Traditional Pharmacy, School of Traditional Medicine, Shahid Beheshti University of Medical Sciences, Tehran, Iran

${ }^{4}$ Center for Research and Training in Skin Diseases and Leprosy (CRTSDL), Tehran University of Medical Sciences, Tehran (TUMS), Iran
\end{abstract}

*Corresponding author: Dr. Mojgan Tanaz, Department of Traditional Medicine School of Traditional Medicine, Shahid Beheshti University of Medical Sciences, Tehran, Iran

\begin{abstract}
Vaginitis is an inflammation process which can be caused by multiple factors and conditions. Although pathological effects of vaginitis have been widely considered, molecular and cellular mechanisms for these pathologies are not well understood. Identification of underlying mechanisms and signaling pathways related to vaginitis gives us valuable information regarding the way for developing a better clinical approach and disease treatment. General complications include preterm labor, urinary tract infections, infertility and pelvic inflammatory disease. Oxidative stress (OS) and antioxidants depletion is likely a main reason for vaginitis development and pathology. Recent evidences have indicated that mucosa vagina samples of patients with vaginitis is associated with antioxidants depletion such as catalase (CAT) and glutathione (GSH), overproduction of reactive oxygen species (ROS), DNA fragmentation, and increased level of apoptosis biomarkers. Therefore, OS plays an important role in the development and pathogenesis of vaginitis. According to these data, antioxidant therapy seems to be helpful for mitigating of OS and vaginitis treatment. Nevertheless, there are a limited published data in this regard. In this review, we aimed to discuss the etiology of vaginitis, the importance of oxidative stress and antioxidants depletion in vaginitis development and pathogenesis along with research on antioxidant therapy as a suitable antidote.
\end{abstract}

\section{Keywords}

Vaginitis, Oxidative stress, Inflammation, Antioxidant therapy

\section{Introduction}

Vaginitisis an inflammation of the vagina which is associated with multiple complications such as preterm labor, urinary tract infections, and pelvic inflammatory disease. It has been described as a remarkably common medical problem which needs special care by health care providers [1]. It includes a spectrum of conditions that causes vaginal or vulvar symptoms like itching, burning, irritation and discharge and bad odor [2]. Vaginitis influences women's quality of life by inducing vulvovaginal discomfort, sexual dysfunction and anxiety. Moreover, it may affect negatively outcomes of pregnancy, pelvic inflammatory disease (PID), sexually transmitted disease (STD) and reproductive health [3]. The majority of women with vaginal complaints use over- thecounter (OTC) drugs and self-treat inappropriately [4]. Therefore, it is essential to diagnose the vaginitis properly, possible underlying mechanisms, and initiate an appropriate therapeutic method. In practice, vaginal complaints are usually treated empirically based on patient's complaints [5]. However, studies have revealed weak association between symptoms and the final diagnosis of vaginitis [6]. Definite diagnosis of vaginitis needs a thorough examination, cultures, $\mathrm{pH}$ determi-

Citation: Moghadam FH, Tansaz M, Aminimoghaddam S, Hajimehdipoor H, Hosseini H (2021) Vaginitis: Etiology and Role of Oxidative Stress, Inflammation and Antioxidants Therapy. Reprod Med Int 4:014. doi.org/10.23937/2643-4555/1710014

Accepted: March 06, 2021: Published: March 08, 2021

Copyright: (C) 2021 Moghadam FH, et al. This is an open-access article distributed under the terms of the Creative Commons Attribution License, which permits unrestricted use, distribution, and reproduction in any medium, provided the original author and source are credited. 
nation and wet mount microscopy [7]. Management of this condition induces health care costs.

Recent studies have shown that reactive oxygen species (ROS) and oxidative stress (OS) caused by antioxidant depletion are a main underlying mechanism for vaginitis [8]. Data suggest that antioxidant therapy may induce antioxidant response to the oxidative stress and cause vaginitis improvement, while antioxidants depletion can be associated with ROS overproduction, oxidative stress and consequently vaginitis [9]. Therefore, oxidative damage seems to be a major risk factor for vaginitis development. In the current review, the etiology, different types of vaginitis, symptoms and diagnosis, current treatments, role of oxidative stress and inflammation, as well as antioxidant therapy in patients with vaginosis were considered.

\section{Materials and Methods}

The articles described in this review were obtained by searching Medline, Scopus, and ISI Web of Knowledge. We searched articles that published from April 1980 to June 2020. To identify relevant articles, the following keywords: "Bacterial vaginosis and oxidative stress/inflammation", "vulvovaginal candidiasis and oxidative stress/inflammation" and "antioxidant therapy for vaginitis", were used. Relevant articles, at least to some degree, had to examine the relationship between antioxidant supplementation with oxidative stress/inflammation in vaginitis. Ultimately, a total of 57 articles were selected, in which 11 articles considered the relationship between oxidative stress and vaginitis. The articles included original in vivo, in vitro and human studies. All of these articles were published as peer-reviewed journals.

\section{Results}

\section{Vaginitis epidemiology}

Finding the exact pathologic factor for vaginitis is crucial to treat the disease accurately so it is clinically important to discover the incidence of vaginitis in various areas. Prevalence of vaginitis is different among races and geographical locations [10]. Annually most visits to clinics are due to vaginal discharge [11]. Evaluation the incidence of bacterial vaginosis (BV) and vulvovaginal candidiasis (VVC) is difficult since most of BV cases are asymptomatic and cases with VVC usually treat themselves by OTC drugs. Estimations by WorId health organization (WHO) revealed that more than 340 million new cases with sexually transmitted diseases happen each year and $75-85 \%$ occurs in developing countries [12]. It can be explained by the relationship between STDs and vaginitis. For example, BV is associated with the prevalence and incidence of multiple STIs including chlamydia, gonorrhea, herpes, HIV and trichomoniasis. Various factors are known to be associated with infectious vaginitis such as parity, poor socioeconomic status, poor menstrual hygiene and illiteracy [12]. According to US National Health and Nutrition survey prevalence of $\mathrm{BV}$ is about $20-30 \%$ among women in reproductive age [13]. VVC is the second most prevalent cause for vaginitis after BV, candidiasis is found in more than $30 \%$ of women in reproductive age and in $6-7 \%$ of menopausal women [14].

\section{Types of vaginitis and etiologies}

Infectious vaginitis: Vaginitis can be divided into two main groups, including infectious and non-infectious vaginitis (Figure 1). Non-infectious vaginitis can be categorized as: Atrophic vaginitis, allergic vaginitis, foreign body, chemical irritation, desquamative vaginitis and lichen planus [15]. On the other hand, infectious vaginitis includes Bacterial vaginosis, Vulvovaginal candidiasis and Trichomoniasis [1]. The majority of infectious causes of vaginitis are Candida albicans, BV and trichomoniasis [1]. The mentioned infections usually treat with appropriate medications properly.

Bacterial vaginosis: In the US, approximately $30 \%$ of women have had BV in their life. BV is caused by disturbance in normal vaginal microflora and is the most pre-

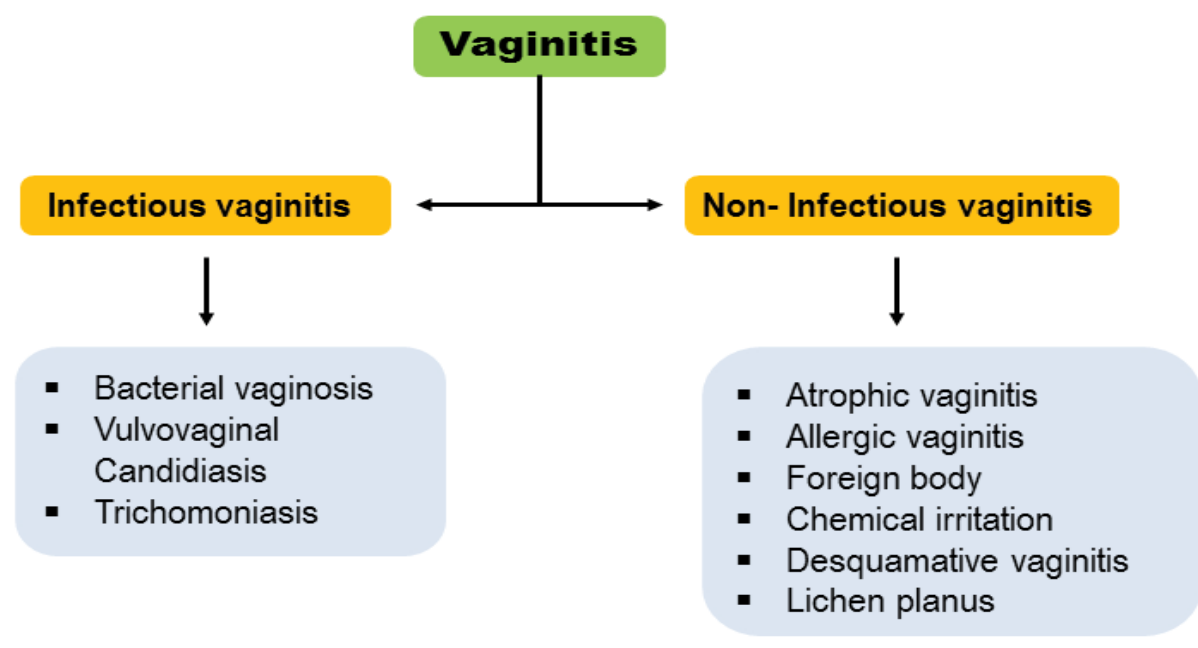

Figure 1: Types of vaginitis. 
valent cause of vaginal discharge in reproductive-aged women [16]. Gardnerella vaginalis is a main bacterium in the etiology of BV [17]. Although a reduction in hydrogen peroxide producing lactobacilli in association with anaerobic and facultative bacteria are the other known etiologies for the disease [18]. BV is associated with increased risk of preterm labor, PID and STD [19]. Almost $50 \%$ of women with BV are asymptomatic; however, some report fishy smell and thin homogenous vaginal discharge [18]. Diagnosis of BV commonly can be made by clinical manifestations and wide variety of diagnostic assays like gram stains and cultures. Gram stain is the gold standard for diagnosis of BV which presence of clue cells makes the diagnosis. Recently, new methods using molecular techniques have been developed for diagnosis of BV. These tests are based on bacterial nucleic acid detection. Multiplex polymerase chain reaction (PCR) assay is most useful for diagnostic approach in women with recurrent vaginosis. The suggested treatment for $\mathrm{BV}$ is oral Metronidazole $500 \mathrm{mg}$ twice per day for 7 days or intravaginal metronidazole $0.75 \%$ gel (for those with gastrointestinal symptoms with oral metronidazole) once per day for 5 days. In women who are allergic to metronidazole intravaginal Clindamycin $2 \%$ cream daily for 7 days is recommended [20]. Human immunodeficiency virus (HIV) positive women are treated the same as other cases. In pregnancy BV is associated with poor consequences. All symptomatic pregnant women should be treated with one of the following regimen: Metronidazole $500 \mathrm{mg}$ orally twice daily for 7 days, metronidazole $250 \mathrm{mg}$ orally three times per day for 7 days or Clindamycin $300 \mathrm{mg}$ orally twice daily for 7 days [20]. Recurrent BV should be confirmed by Gram stain and treated by 10-14 days of treatment with Metronidazole $500 \mathrm{mg}$ twice daily. Relapse of BV after ceasing the therapy is a common event with extended therapy. Tinidazole is recommended for cases with refractory BV [21].

Vulvovaginal candidiasis: Vulvovaginal candidiasis (VVC) is the second most common (20-25\%) cause of vaginitis after BV [22]. VVC is usually attributed to imbalance between vaginal colonization of Candida and host environment secondary to physiological or non-physiological alterations. Candida albicans accounts for about $85-90 \%$ of the cases. Although, non-Candida albicans species particularly Candida glabrata seems to be increasing [23]. Most women carry Candida as normal flora of vagina without any symptoms [24]. This opportunistic germ can transform from symptom free colonization into an infection. The disease is characterized by non-specific symptoms like vulvar pruritus along with abnormal "cheese-like" discharge, dyspareunia or dysuria which may be associated with other vaginal infections including BV, trichomoniasis or gonorrhea [25]. Nevertheless, in severe immunosuppression it can transform to a serious systemic infection [26]. In physical examination erythema, edema or fissures of vulva or vagina is found. There are several known behavioral and host predisposing factors for VVC such as any condition with increased level of estrogen such as pregnancy, uncontrolled diabetes mellitus, immunosuppression, glucocorticoids use, antibiotics intake, intrauterine device, condoms and clothing. Sexual activity is known to be associated with higher incidence of VVC. Recurrent symptoms (four or more episodes per year) are quite common among women and classified as complicated VVC [27]; however, it happens due to Candida just in one third of cases [28]. Diagnosis of VVC is based on clinical symptoms and signs and finding yeast hyphae on potassium hydroxide microscopy. Antigen or DNA probe testing is also helpful [15]. Complicated form of the disease is diagnosed by culture to determine non-albicans form of Candida. First-line therapy for VVC includes oral or topical form of azoles. Oral Fluconazole as single 150 $\mathrm{mg}$ dose is a convenient and effective treatment. Patient preference and any previous experience with these drugs should be considered while choosing the treatment. Considering pregnant women only topical azole therapy for duration of 7 days is recommended by CDC [20]. For severe VVC a second dose of Fluconazole for 3 days following the first dose is shown to be effective [29].

Trichomoniasis: Trichomonas vaginalis (TV) is the most common non-viral STD throughout the world, with 276.4 million cases annually [30]. In all women with vaginitis who are at risk for STD (multiple sex partners, illicit drug use, history of STD), trichomoniasis should be considered as a possible diagnosis. TV can be easily transmitted by sexual contact and is associated with high risk (2-3 fold increase) of HIV infection [20]. Symptoms of TV in women include itching, painful intercourse, frothy yellow-green discharge and vaginitis. However, most of cases have minimal symptoms which lead to untreated infections [20]. In clinical exam, hemorrhagic spots may be seen on vaginal or cervical surface which is called "strawberry cervix". Infections with TV in men are usually asymptomatic however mild urethritis, epididymitis and prostatitis might happen [31]. TV can be associated with several complications like urethritis, cervicitis, PID, cervical cancer and infertility [32]. Diagnosis of TV is made by saline microscopy which reveals motile flagellated protozoa. CDC recommends nucleic acid amplification tests for diagnosis of trichomoniasis because they have higher sensitivity (95-100\%) compared to saline microscopy (51-65\%) [20]. Due to high rate of recurrence, diagnostic tests must be repeated 3 months after therapy [20]. Treatment of the disease can diminish symptoms and reduce transmission to sexual partners. First-line therapy includes a single 2- gram dose of Metronidazole for pregnant and non-pregnant women. However, in women with HIV infection a 7 days course of Metronidazole is suggested [33]. In pregnancy, trichomoniasis is associated with negative outcomes like low birth weight, preterm labor and neonatal genital or nasopharyngeal infections [34]. Affected pregnant women must be checked and treated at any stage of pregnancy. 


\section{Noninfectious vaginitis}

Account for $5-10 \%$ of cases with vaginitis. Some of less common types of vaginal inflammation may be due to atrophic vaginitis, allergic vaginitis, foreign body, chemical irritation, lichen planus and desquamative vaginitis [11]. Treatment should be done based on the underlying cause.

Atrophic vaginitis: Genitourinary syndrome of menopause is caused by low estrogen level that affects $>$ $50 \%$ of post-menopausal females [35]. Symptoms include vaginal dryness, itching, and dyspareunia urinary tract infections. Most of the affected women hesitate to seek medical help, causing delay in diagnosis and treatment. Atrophy related vulvovaginitis is treated with low-dose vaginal estrogen in the form of cream, tablet or ring. Non-hormonal alternatives include vaginal lubricants, laser therapy and homeopathic remedies for those with minor symptoms and sustained sexual activity for women with sexual dysfunction [36].

Allergic vaginitis: Vaginal mucosa is able to show an allergic response. Several allergens and conditions such as the airborne allergens, the influence of hormones, the immunology of the vagina, menstrual cycle, and psychologic factors can provoke allergic reactions in women's genital system [37]. Candida albicans is a major cause of Allergic vaginitis [38,39]. However, allergic reactions to Candida albicans are not commonly known or recognized [40].

Foreign body: Foreign body in vagina is a rare cause of vaginitis in prepubertal girls [41]. Previous studies found different foreign bodies in children, including safety pins, hairpins, bits of folded paper, crayons, twigs, splinters of wood, cherries, plum pits, paper clips, beads, bits of toys, pencil erasers, sand, stones, marbles, cotton, shells, nuts, corks, and even insects [42].

\section{Role of oxidative stress and inflammationin vagi- nitis}

Oxidative stress is an imbalance between the production of ROS and the ability of body cells to neutralize their harmful effects through antioxidant defense systems [43]. OS can lead to a critical failure of cellular functions and eventually cell death. Free radicals such as superoxide anion $\left(\mathrm{O}_{2}{ }^{\circ}\right)$ and hydroxyl radicals $\left(\mathrm{OH}^{\circ}\right)$ are highly reactive and unstable compounds which are produced by body cells as a result of normal intracellular metabolism [44]. Mitochondria, phagocyte cells, peroxisomes, cytochrome $\mathrm{P} 450$ enzymes, nicotinamide adenine dinucleotide phosphate (NADPH) oxidases, inducible nitric oxide synthesis (iNOS) and hemeproteins are the source of ROS production in cells [45]. Although free radicalsplay physiological roles at low concentrations, they can react with cellular components such as DNA, proteins and lipids at high concentrations. DNA damages induced by free radicals can be associated with chromosome instability, altered expression of various genes, and genetic mutation which can subsequently cause cell death or apoptosis. Free radicals can also trigger protein and lipid oxidation, which can negatively affect the functional activity of numerous enzymes, structural proteins and cells membrane fluidity. Many studies have suggested that oxidative stress induced by overproduction of ROS may be involved in the pathogenesis of various diseases from diabetes to male infertility [43], Alzheimer's disease (AD) and cancers [46].

Recent studies have indicated that oxidative stress and inflammation may be a main reason for vaginitis development (Table 1). For this reason, recent evidences have suggested that antioxidants supplementation may be helpful to mitigate oxidative stress damages in vaginitis. Chen, et al. [47] evaluated oxidative stress bio-

Table 1: Oxidative stress biomarkers in patients with vaginitis.

\begin{tabular}{|c|c|c|}
\hline Samples & Results & References \\
\hline $\begin{array}{l}100 \text { female patients with nonspecific } \\
\text { vaginitis }\end{array}$ & $\begin{array}{l}\uparrow \text { mucosa epithelial cell apoptosis; } \uparrow \text { MDA; } \uparrow \mathrm{H}_{2} \mathrm{O}_{2} ; \uparrow D N A \text { damage } \\
\text { of mucosa epithelial cells; } \uparrow \text { caspase } 3 \text { expression; } \downarrow \text { Bcl2; } \uparrow \text { Bax; } \\
\uparrow \text { cytochrome C in mucosa epithelial cells; } \downarrow \text { CAT activity; } \uparrow S O D\end{array}$ & {$[47]$} \\
\hline 257 patients with vaginitis & $\uparrow M D A ; \uparrow \mathrm{H}_{2} \mathrm{O}_{2} ; \downarrow$ CAT activity; $\downarrow$ vitamin $\mathrm{C}$ levels & [8] \\
\hline 35 women with bacterial vaginosis & $\uparrow$ Number of epithelial cells; $\uparrow$ caspase-3; $\uparrow$ apoptosis; $p-\uparrow l k B a ; \uparrow c-F o s$ & [48] \\
\hline 45 women with vaginitis & $\begin{array}{l}\uparrow \text { Serum disulphide level; } \uparrow \text { serum disulphide/native } \\
\text { thiol ratio; } \downarrow \text { native /total thiol; } \uparrow \text { oxidative stress; } \uparrow \text { inflammation }\end{array}$ & [49] \\
\hline $\begin{array}{l}24 \text { women with vulvovaginal candidiasis } \\
\text { and cytolytic vaginosis }\end{array}$ & $\uparrow$ Oxidative stress; $\uparrow$ inflammation; $\uparrow$ apoptosis & {$[50]$} \\
\hline $\begin{array}{l}\text { Co-cultured human monocyte-derived } \\
\text { macrophages with } T \text {. Vaginalis }\end{array}$ & $\uparrow T N F-\alpha, \uparrow I L-1 \beta, \uparrow I L-6 ; \uparrow$ nitric oxide; $\uparrow$ iNOS & [51] \\
\hline $\begin{array}{l}\text { Incubation of human neutrophils with } T . \\
\text { Vaginalis }\end{array}$ & $\uparrow R O S ; \uparrow$ caspase- 3 activation; $\uparrow$ apoptosis & [52] \\
\hline Plasma and tissue samples of diabetic rats & $\downarrow$ MDA; $\downarrow$ glutathione; $\downarrow$ ascorbic acid & [53] \\
\hline
\end{tabular}




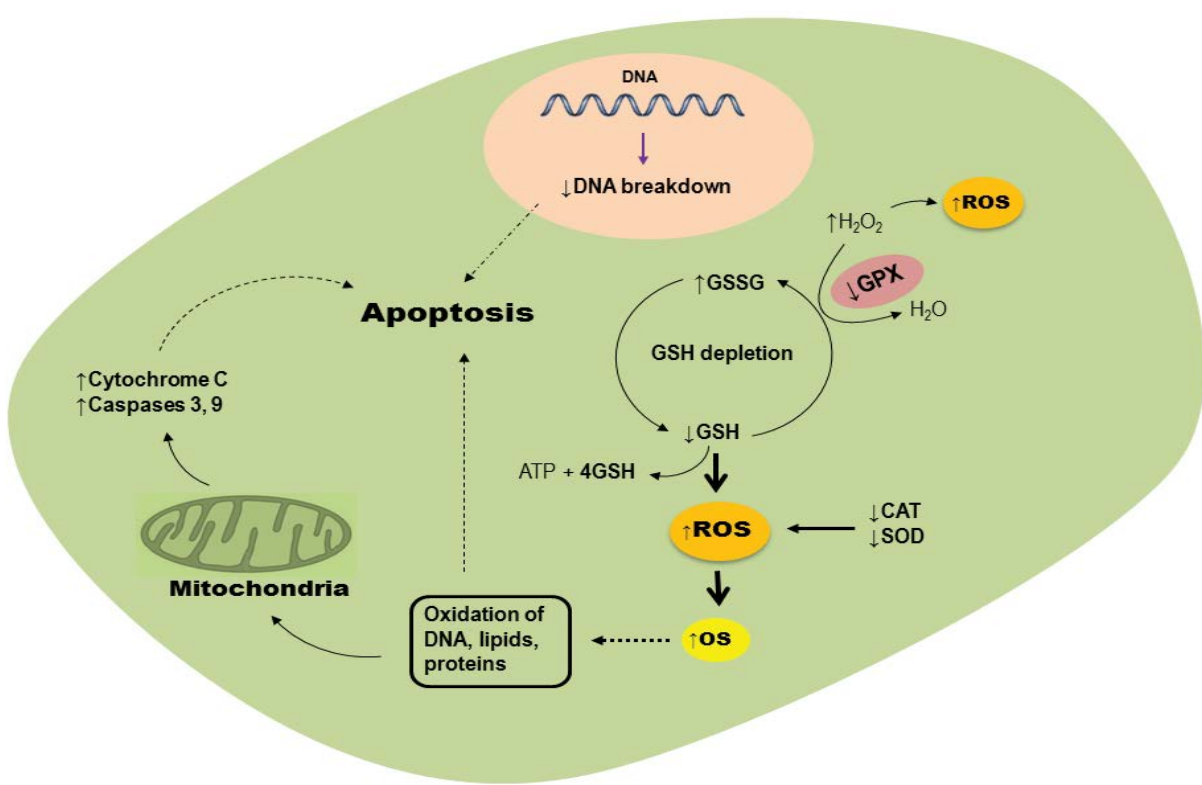

Figure 2: Role of oxidative stress in mucosa epithelial cells of patients with vaginitis.

marker in mucosa epithelial cells of 100 female patients with nonspecific vaginitis compared to healthy women. They found increased level of OS biomarkers such as malondialdehyde (MDA), hydrogen peroxide $\left(\mathrm{H}_{2} \mathrm{O}_{2}\right)$, antioxidants depletion, and DNA breakage in mucosa epithelial cells (Figure 2). More importantly, increased level of apoptosis biomarkers such a Bax, Caspase 3 and cytochrome $\mathrm{C}$ was found in mucosa epithelial cells of these patients (Figure 2). In another study, Guo, et al. [8] reported increased levels of MDA and $\mathrm{H}_{2} \mathrm{O}_{2}$, but decreased catalase (CAT) and vitamin $\mathrm{C}$ levels in cervico-vaginal fluid of patients with vaginitis. Desdicioglu, et al. [49] compared the amount of serum disulphide level, as well as the percentage of disulphide/nativethiol ratio and native/total thiol ratio between women with vaginitis and healthy females. They observed that patients with vaginitis had lower serum native/total thiol ratio, but higher disulphide level and percentage of disulphi$\mathrm{de} /$ nativethiol ratio compared to healthy women. Since naïve thiol groups are essential for the activity of several antioxidant enzymes, these researcher concluded that oxidative stress and inflammatory reaction are a main reason for vaginitis development in these patients. Increased levels of proinflammatory cytokines, such as Tumor Necrosis Factor- $\alpha$ (TNF- $\alpha$ ), Interleukin $1 \beta($ IL-1 $\beta)$, and IL-6, nitric oxide (NO) production and expression of iNOS were found in human monocyte-derived macrophages (HMDM) were co-cultured with $T$. Vaginalis [51]. A recent study has reported higher levels of oxidative stress, inflammation and apoptosis biomarkers in women with vulvovaginal candidiasis and cytolytic vaginosis compared to healthy cases [50]. Similarly, Song, et al. revealed that $T$. Vaginalis induces ROS generation, caspase-3 activity and subsequently apoptosis of human neutrophils [52]. All of these data indicate that vaginal mucosa epithelial cells in patients with vaginitis undergo oxidative stress, inflammatory reaction and mitochondrial pathway induced apoptosis (Figure 2). Therefore, oxidative stress played an important role in vaginitis and antioxidant therapy seems to be helpful for the treatment of vaginitis.

\section{Roles of antioxidants therapy in patients with va- ginitis}

Since oxidative stress may play an important role in vaginitis development, recent studies have suggested that antioxidant therapy can be used for the treatment of the disease; however, there are a limited number of studies in this regard (Table 2). In a clinical trial study, Petersen and Magnani [56] investigated the effect of $\mathrm{Vi}$ tamin C vaginal tablets $(250 \mathrm{mg} /$ day) in the treatment of non-specific vaginitis. They found that Vitamin C administration significantly improved main symptoms of vaginitis, including clue cells disappearing, bacteria disappearing, lactobacilli reappearing and decreasing vaginal $\mathrm{pH}$, in the study group.

In the study by Chen, et al. [47] 100 patients with vaginitis were treated with $250 \mathrm{mg}$ Vitamin C vaginal tablets every day for one week. Their findings showed that Vitamin C therapy can significantly control the amount of oxidative stress biomarkers, and OS-induced cell apoptosis in mucosa epithelial cells. More recently, Roselletti, et al. [48] evaluated oxidative stress induced apoptosis of vaginal epithelial cells in women with BV. They indicated that vaginitis is associated with increased number of epithelial cells, biomarkers of inflammation, caspase-3 activity and consequently apoptosis. Therefore, they concluded that vaginitis is strongly associated with apoptosis induction vaginal epithelial cells. In another study, Angelucci, et al. [55] investigated the effect of oral supplementation of several supplementations, especially vitamins $A, C$ and Eon vaginal dryness in young women. They found that antioxidant supplemen- 
Table 2: Antioxidant therapy in patients with vaginitis.

\begin{tabular}{|c|c|c|c|}
\hline Samples & Antioxidants & Results & References \\
\hline $\begin{array}{l}100 \text { female patients with nonspecific } \\
\text { vaginitis }\end{array}$ & $\begin{array}{l}\text { Vitamin C therapy } \\
(250 \mathrm{mg} / \text { day/one week) }\end{array}$ & $\begin{array}{l}\downarrow \text { vaginal MDA; } \downarrow \text { vaginal } \mathrm{H}_{2} \mathrm{O}_{2} ; \downarrow \text { mucosa } \\
\text { epithelial cell apoptosis; } \downarrow \text { DNA damage } \\
\text { ofmucosa epithelial cells; } \downarrow \text { caspase } 3 \\
\text { expression; } \uparrow \text { Bcl } 2 ; \downarrow \text { Bax; } \downarrow \text { cytochrome C } \\
\text { in mucosa epithelial cells }\end{array}$ & {$[47]$} \\
\hline 180 patients with bacterial vaginosis & $\begin{array}{l}\text { Berberine } \\
\text { (as posterior vaginal fornix at } \\
0.3 \text { g/daily for } 10 \text { days) }\end{array}$ & $\begin{array}{l}\uparrow S O D ; \quad \uparrow C A T ; \quad \downarrow \mathrm{H}_{2} \mathrm{O}_{2} ; \quad \downarrow \text { caspase-3, } \\
\downarrow \text { cytochrome C, } \downarrow \text { capase-12; } \downarrow \text { Bax; } \uparrow \text { Bcl- } \\
2 ; \downarrow \text { Bax/Bcl-2 ratio in vaginal discharge }\end{array}$ & {$[54]$} \\
\hline $\begin{array}{l}35 \text { women with vaginal } \\
\text { dryness }\end{array}$ & $\begin{array}{l}\text { Vitamins A, C and E; } \\
\text { hyaluronic acid; collagen; } \\
\text { glucosamine sulfate; } \\
\text { chondroitin sulfate; } \\
\text { alpha-lipoic acid; } \\
\text { methylsulfonylmethane }\end{array}$ & $\begin{array}{l}\uparrow \text { Vaginal Health Index; } \uparrow \text { Female Sexual } \\
\text { Function } \downarrow \text { Index; oxidative stress }\end{array}$ & {$[55]$} \\
\hline $\begin{array}{l}100 \text { women with non-specific vaginal } \\
\text { dryness }\end{array}$ & $\begin{array}{l}\text { Vitamin } \mathrm{C} \text { vaginal tablets } \\
(250 \mathrm{mg}) \text { once a day for a } \\
\text { total of } 20 \text { days }\end{array}$ & $\begin{array}{l}\uparrow \text { Bacteria disappeared; } \downarrow \text { Vaginal } \mathrm{pH} \text {; } \\
\downarrow \text { clue cells; } \uparrow \text { lactobacilli reappeared; } \\
\uparrow \text { vaginitis improvement }\end{array}$ & {$[56]$} \\
\hline
\end{tabular}

tation caused a significant improvement in vaginal health index and female sexual function in $87 \%$ of patients. They suggested that antioxidant supplementation improves these parameters possibly by mitigating of oxidative stress and inflammation. Due to antioxidant and anti-inflammatory effects of natural compounds and plants, recent studies have suggested the use of several medical plants or natural compounds for the treatment of vaginitis [57]. For example, Ma, et al. [54] investigated the effect of a natural alkaline product, Berberine, on oxidative stress and apoptosis biomarkers in 180 patients with BV. They found that Berberine treatment not only decreases apoptosis and oxidative stress biomarkers of vaginal epithelial cells, but also improves the amount of antioxidants such as CAT and superoxide dismutase (SOD) in these patients.

\section{Conclusion}

Although multiple factors are involved in the etiology of vaginitis, oxidative stress and apoptosis is one of main reason for the development and pathogenesis of vaginitis. An increasing number of evidence suggests that OS induced by ROS is likely a main mechanism of vaginitis development and pathogenesis which is associated with antioxidants depletion, DNA fragmentation, lipid and protein oxidation, inflammation, accumulation of leukocytes at the site of damaged tissues, as well as cells apoptosis and tissue damage. Therefore, the discovery and development of potent antioxidants is one of the most interesting and promising approaches for treatment of patients with vaginitis. Antioxidants have positive effects in protecting nucleic acids, proteins, and lipids against oxidative damages. Thus, antioxidant therapy may have successful effects against vaginitis.
However, successful therapy may depend on disease severity, antioxidants dosage, combined therapy with other compounds and their improved delivery to target tissues.

\section{Declaration of Interest}

All authors approve the manuscript and declare that there is no conflict of interest.

\section{Author's Contribution}

First of all, I would like to express that this paper and the research behind it is a part of a Ph.D thesis. Further, I would like to thank my supervisor Dr. Mojgan Tansaz for the thoughtful comments and recommendations on this dissertation. I am also thankful to the School of Traditional Medicine and all its member's staff for all the considerate guidance.

\section{References}

1. Hainer BL, Gibson MV (2011) Vaginitis. Am Fam Physician 83: $807-815$

2. Reid G (2018) Is bacterial vaginosis a disease? Appl Microbiol Biotechnol 102: 553-558.

3. Cohen CR, Lingappa JR, Baeten JM, Ngayo MO, Spiegel CA, et al. (2012) Bacterial vaginosis associated with increased risk of female-to-male HIV-1 transmission: a prospective cohort analysis among African couples. PLoS Med 9: e1001251.

4. Ferris DG, Nyirjesy P, Sobel JD, Soper D, Pavletic A, et al. (2002) Over-the-counter antifungal drug misuse associated with patient-diagnosed vulvovaginal candidiasis. Obstet Gynecol 99: 419-425.

5. Sarier M, Sepin Ozen N, Guler H, Duman I, Yüksel Y, et al. (2018) Prevalence of sexually transmitted disease in asymptomatic renal transplant recipients. Experimental and Clinical Transplantation. 
6. Wilson $J(2004)$ Managing recurrent bacterial vaginosis. Sex Transm Infect 80: 8-11.

7. Sparks JM (1991) Vaginitis. J Reprod Med 36: 745-752.

8. Guo HY, Hu XM, Han DD, Wang ZP, Meng L (2013) Lipid peroxidation and antioxidant status in vagina microenvironment of patients with several common vaginitis. Clin Exp Obstet Gynecol 40: 331-336.

9. Kalia N, Kaur M, Sharma S, Singh J (2019) Impaired PRR expression modulates inflammation-triggered oxidative stress and pathogenesis of recurrent vulvovaginal infections. Bulletin of the National Research Centre 43: 109.

10. Wang H, Huang Z, Wu Z, Qi X, Lin D (2017) An epidemiological study on vaginitis in 6,150 women of reproductive age in Shanghai. New Microbiol 40: 113-118.

11. Mashburn J (2006) Etiology, diagnosis, and management of vaginitis. J Midwifery Womens Health 51: 423-430.

12. Sianou A, Galyfos G, Moragianni D, Baka S (2017) Prevalence of vaginitis in different age groups among females in Greece. J Obstet Gynaecol 37: 790-794.

13. Brabant $G$ (2016) Bacterial vaginosis and spontaneous preterm birth. Journal de Gynecologie, Obstetrique et Biologie de la Reproduction 45: 1247-1260.

14. Vicariotto F, Del Piano M, Mogna L, Mogna G (2012) Effectiveness of the association of 2 probiotic strains formulated in a slow release vaginal product, in women affected by vulvovaginal candidiasis: A pilot study. J Clin Gastroenterol 46: S73-S80.

15. Paladine HL, Desai UA (2018) Vaginitis: Diagnosis and Treatment. Am Fam Physician 97: 321-329.

16. Coleman JS, Gaydos CA (2018) Molecular Diagnosis of Bacterial Vaginosis: an Update. J Clin Microbiol 56: e00342-e00418.

17. Machado A, Jefferson KK, Cerca N (2013) Interactions between Lactobacillus crispatus and Bacterial Vaginosis (BV)-Associated Bacterial Species in Initial Attachment and Biofilm Formation. Int J Mol Sci 14: 12004-12012.

18. Koumans EH, Sternberg M, Bruce C, McQuillan G, Kendrick J, et al. (2007) The prevalence of bacterial vaginosis in the United States, 2001-2004; associations with symptoms, sexual behaviors, and reproductive health. Sex Transm Dis 34: 864-869.

19. Klebanoff MA, Hillier SL, Nugent RP, MacPherson CA, Hauth JC, et al. (2005) Is bacterial vaginosis a stronger risk factor for preterm birth when it is diagnosed earlier in gestation? American Journal of Obstetrics and Gynecology 192 470-477.

20. Workowski KA, Bolan GA (2015) Sexually Transmitted Diseases Treatment Guidelines, 2015. Recommendations and Reports 64: 1-137.

21. Ariella Baylson F, Nyirjesy P, Velma Weitz M (2004) Treatment of recurrent bacterial vaginosis with tinidazole. Obstet Gynecol 104: 931-932.

22. Martin Lopez JE (2015) Candidiasis (vulvovaginal). BMJ Clin Evid 2015: 0815.

23. Gonçalves B, Ferreira C, Tiago Alves C, Henriques M, Azeredo J, et al. (2016) Vulvovaginal candidiasis: Epidemiology, microbiology and risk factors. Crit Rev Microbiol 42: 905-927.

24. Beigi RH, Meyn LA, Moore DM, Krohn MA, Hillier SL (2004) Vaginal yeast colonization in nonpregnant women: a longitudinal study. Obstetrics and Gynecology 104: 926-930.
25. Anderson MR, Klink K, Cohrssen A (2004) Evaluation of vaginal complaints. JAMA 291: 1368-1379.

26. Ascioglu S, Rex JH, de Pauw B, Bennett JE, Bille J, et al. (2002) Defining opportunistic invasive fungal infections in immunocompromised patients with cancer and hematopoietic stem cell transplants: An international consensus. Clin Infect Dis 34: 7-14.

27. Achkar JM, Fries BC (2010) Candida infections of the genitourinary tract. Clin Microbiol Rev 23: 253-273.

28. Spence D (2010) Candidiasis (vulvovaginal). BMJ Clinical Evidence 2010: 0815.

29. Sobel JD, Kapernick PS, Zervos M, Reed BD, Hooton T, et al. (2001) Treatment of complicated Candida vaginitis: comparison of single and sequential doses of fluconazole. American Journal of Obstetrics and Gynecology 185: 363369.

30. Edwards T, Burke P, Smalley H, Hobbs G (2016) Trichomonas vaginalis: Clinical relevance, pathogenicity and diagnosis. Crit Rev Microbiol 42: 406-417.

31. Guenthner PC, Secor WE, Dezzutti CS (2005) Trichomonas vaginalis-induced epithelial monolayer disruption and human immunodeficiency virus type 1 (HIV-1) replication: Implications for the sexual transmission of HIV-1. Infect Immun 73: 4155-4160.

32. El-Shazly AM, El-Naggar HM, Soliman M, El-Negeri M, ElNemr HE, et al. (2001) A study on Trichomoniasis vaginalis and female infertility. Journal of the Egyptian Society of Parasitology 31 : 545-553.

33. Kissinger P, Mena L, Levison J, Clark RA, Gatski M, et al. (2010) A randomized treatment trial: single versus 7-day dose of metronidazole for the treatment of Trichomonas vaginalis among HIV-infected women. J Acquir Immune Defic Syndr 55: 565-571.

34. Smith LM, Wang M, Zangwill K, Yeh S (2002) Trichomonas vaginalis infection in a premature newborn. Journal of Perinatology 22: 502-503.

35. Gandhi J, Chen A, Dagur G, Suh Y, Smith N, et al. (2016) Genitourinary syndrome of menopause: an overview of clinical manifestations, pathophysiology, etiology, evaluation, and management. American Journal of Obstetrics and Gynecology 215: 704-711.

36. Faubion SS, Sood R, Kapoor E (2017) Genitourinary Syndrome of Menopause: Management Strategies for the Clinician. Mayo Clinic Proceedings 92: 1842-1849.

37. Moraes PS, Taketomi EA (2000) Allergic vulvovaginitis. Ann Allergy Asthma Immunol 85: 253-265.

38. Witkin SS, Jeremias J, Ledger WJ (1988) A localized vaginal allergic response in women with recurrent vaginitis. $J$ Allergy Clin Immunol 81: 412-416.

39. Theodoropoulos DS, Stockdale CK, Duquette DR, Morris MS (2016) Inhalant allergy compounding the chronic vaginitis syndrome: characterization of sensitization patterns, comorbidities and responses to sublingual immunotherapy. Arch Gynecol Obstet 294: 541-548.

40. Blight WJ (1984) Acute Allergic Vaginitis Caused by Candida Albicans. Can Fam Physician 449: 451-452.

41. Chinawa J, Obu H, Uwaezuoke S (2013) Foreign body in vagina: an uncommon cause of vaginitis in children. Ann Med Health Sci Res 3: 102-104.

42. Henderson PA, SCOTT RB (1966) Foreign Body Vaginitis Caused by Toilet Tissue. Am J Dis Child 111: 529-532. 
43. Colagar AH, Marzony ET (2009) Ascorbic Acid in human seminal plasma: determination and its relationship to sperm quality. Journal of Clinical Biochemistry and Nutrition 45: 144-149.

44. Colagar AH, Marzony ET, Chaichi MJ (2009) Zinc levels in seminal plasma are associated with sperm quality in fertile and infertile men. Nutrition Research 29: 82-88.

45. Phaniendra A, Jestadi DB, Periyasamy L (2015) Free radicals: properties, sources, targets, and their implication in various diseases. Indian Journal of Clinical Biochemistry 30: 11-26.

46. Yen CY, Hou MF, Yang ZW, Tang JY, Li KT, et al. (2015) Concentration effects of grape seed extracts in anti-oral cancer cells involving differential apoptosis, oxidative stress, and DNA damage. BMC Complementary and Alternative Medicine 15: 94.

47. Chen Z, Zhang Z, Zhang H, Xie B (2015) Analysis of the Oxidative Stress Status in Nonspecific Vaginitis and Its Role in Vaginal Epithelial Cells Apoptosis. BioMed Research International 2015: 1-7.

48. Roselletti E, Sabbatini S, Perito S, Mencacci A, Vecchiarelli A, et al. (2020) Apoptosis of vaginal epithelial cells in clinical samples from women with diagnosed bacterial vaginosis. Scientific Reports 10: 1-10.

49. Desdicioglu R, Yildirim M, Ozbek B, Kılıc G, Erel O, et al. (2018) Dynamic Thiol/Disulphide Homeostasis in Patients with Vaginitis. Journal of Gynecology and Obstetrics 6: 1-5.

50. Sanches JM, Giraldo PC, Amaral R, Eberlin MN, Marques LA, et al. (2018) Vaginal lipidomics of women with vulvovaginal candidiasis and cytolytic vaginosis: A non-targeted LC-MS pilot study. PLoS One 13: e0202401.
51. Han IH, Goo SY, Park SJ, Hwang SJ, Kim YS, et al. (2009) Proinflammatory cytokine and nitric oxide production by human macrophages stimulated with Trichomonasvaginalis. Korean J Parasitol 47: 205-212.

52. Song HO, Shin MH, Ahn MH, Min DY, Kim YS, et al. (2008) Trichomonas vaginalis: reactive oxygen species mediates caspase-3 dependent apoptosis of human neutrophils. Exp Parasitol 118: 59-65.

53. Kustimur S, Kalkanci A, Akbulut G, Gonul B, Bulduk E, et al. (2007) The effect of vaginal candidiasis on the levels of the oxidative biomarkers in plasma and tissue samples of diabetic rats. Mycopathologia 164: 217-224.

54. Ma X, Deng J, Cui X, Chen Q, Wang W (2019) Berberine exhibits antioxidative effects and reduces apoptosis of the vaginal epithelium in bacterial vaginosis. Experimental and Therapeutic Medicine 18: 2122-2130.

55. Angelucci M, Frascani F, Garo ML (2019) Efficacy of an oral supplement containing hyaluronic acid, collagen, glucosamine sulfate, chondroitin sulfate, alpha-lipoic acid, methylsulfonylmethane and vitamins on vaginal dryness in young women. Nutrafoods 1: 58-67.

56. Petersen EE, Magnani P (2004) Efficacy and safety of vitamin $C$ vaginal tablets in the treatment of non-specific vaginitis: A randomised, double blind, placebo-controlled study. Eur J Obstet Gynecol Reprod Biol 117: 70-75.

57. Khalizadeh S, Eftekhar T, Rahimi R, Mehriardestani M, Tabarrai M (2019) An Evidence-Based Review of Medicinal Plants Used for the Treatment of Vaginitis by Avicenna in "the Canon of Medicine". Galen Medical Journal 8: e1270. 